\title{
Re-evaluation of the optimum dietary protein level for maximum growth of juvenile barred knifejaw Oplegnathus fasciatus reared in cages
}

Kang-Woong Kim¹, Mohammad Moniruzzaman², Kyoung-Duck Kim', Hyon Sob Han', Hyeonho Yun², Seunghan Lee ${ }^{2}$ and Sungchul C. Bai ${ }^{2^{*}}$

\begin{abstract}
We determined the optimum dietary protein level in juvenile barred knifejaw Oplegnathus fasciatus in cages. Five semi-purified isocaloric diets were formulated with white fish meal and casein-based diets to contain 35, 40, 45, 50, and $60 \%$ crude protein (CP). Fish with an initial body weight of $7.1 \pm 0.06 \mathrm{~g}$ (mean \pm SD) were randomly distributed into 15 net cages (each size: $60 \mathrm{~cm} \times 40 \mathrm{~cm} \times 90 \mathrm{~cm}, W \times L \times H$ ) as groups of 20 fish in triplicates. The fish were fed at apparent satiation level twice a day. After 8 weeks of feeding, the weight gain (WG) of fish fed 45, 50, and $60 \%$ CP diets were significantly higher than those of fish fed 35 and $40 \%$ CP diets. However, there were no significant differences in WG among fish fed 45, 50, and $60 \%$ CP diets. Generally, feed efficiency (FE) and specific growth rate (SGR) showed a similar trend as WG. However, the protein efficiency ratio (PER) was inversely related to dietary protein levels. Energy retention efficiency increased with the increase of dietary protein levels by protein sparing from non-protein energy sources. Blood hematocrit content was not affected by dietary protein levels. However, a significantly lower amount of hemoglobin was found in fish fed $35 \% \mathrm{CP}$ than in fish fed $40,45,50$, and $60 \%$ CP diets. Fish fed $60 \%$ CP showed the lowest survival rate than the fish fed $35,40,45$, and $50 \%$ CP diets. Broken-line analysis of WG showed the optimum dietary protein level was $45.2 \%$ with $18.8 \mathrm{~kJ} / \mathrm{g}$ diet for juvenile barred knifejaw. This study has potential implication for the successful cage culture of barred knifejaw.
\end{abstract}

Keywords: Oplegnathus fasciatus, Barred knifejaw, Optimum protein level, Fish growth, Fish feeds

\section{Background}

Protein is the basic component of all animal tissues, and it constitutes about $65-75 \%$ in fish tissues on a dry matter basis (Wilson 2002). Dietary protein has great impact on the growth and body composition of fish (Lovell 1989) because it provides the essential amino acids for body protein synthesis as well as energy for growth and maintenance. However, protein is one of the most expensive major nutrients in fish feeds, and its inclusion in fish diets has significant

\footnotetext{
* Correspondence: scbai@pknu.ac.kr

${ }^{2}$ Department of Marine Bio-materials and Aquaculture/Feeds and Foods Nutrition Research Center, Pukyong National University, Busan 608-737, Republic of Korea

Full list of author information is available at the end of the article
}

effects on operational costs in aquaculture (NRC 1993). It is well documented that increase of dietary protein can lead to improved fish production especially in the case of carnivorous fish species. However, the excess level of dietary protein will be used for energy and will lead to an increase in ammonia excretion which ultimately deteriorates the fish culture water that may be harmful for fish growth (Catacutan and Coloso 1995; Tibbetts et al. 2000). Furthermore, an inadequate level of dietary protein in aqua feeds can result in the stunted growth of fish. But the objective of proper feed formulation is to produce costeffective feeds with maximum fish production at a minimum protein level (Halver and Hardy 2002). Therefore, it is imperative to determine the optimum 
dietary protein level in aquaculture diets for achieving cost-effective maximum growth of fish together with improved culture environment.

Barred knifejaw, Oplegnathus fasciatus, belonging to the family Oplegnathidae, is a popular food fish and an economically important cage aquaculture species in Korea as well as in East Asia (Meng et al. 1995). In 2014, its aquaculture production in Korea was approximately 884 metric tons (National Statistical Office 2014) which mostly came from cage aquaculture. It has high market value and consumer demand. The dietary protein requirements of several important aquaculture fish species have been determined including channel catfish, Ictalurus punctatus (Garling and Wilson 1976); Asian sea bass, Lates calcarifer (Catacutan and Coloso 1995); Indian major carp, Labeo rohita (Das et al. 1991); Nile tilapia, Oreochromis niloticus (El-Sayed and Teshima 1992); olive flounder, Paralichthys olivaceus (Kim et al. 2005); Korean rockfish, Sebastes schlegelii (Kim et al. 2004), and Japanese eel, Anguilla japonica (Okorie et al. 2007); black sea bass, Centropristis striata (Alam et al. 2008); black sea bream, Sparus macrocephalus (Zhang et al. 2010); and silver pomfret, Pampus argenteus (Hossain et al. 2010). For most of the cultured species, dietary protein requirement has been found to be between 30 and $55 \%$ of the diet depending on the species, fish size, dietary protein sources, and environmental condition (Hepher 1988; NRC 1993). Therefore, it is important to estimate dietary protein requirements in fish under different conditions (Luo et al. 2004). In a previous study, Kang et al. (1998) reported that the optimum dietary protein and lipid levels for parrot fish or barred knifejaw are 46 and $16 \%$, respectively, in a protein and lipid ratio experiment in tanks. However, for the first time, in this study, we aimed to reevaluate the optimum dietary protein level in diets for the juvenile barred knifejaw with a fixed dietary energy level in cage culture condition, which is widely being practiced in Korea.

\section{Methods}

\section{Diet formulation}

Composition of the experimental diets is shown in Table 1. Five experimental diets containing white fish meal and casein as the main protein sources were formulated with protein levels of $35,40,45,50$, or $60 \%$ at the expense of $\alpha$-potato starch and squid liver oil. The diets were formulated to be isocaloric, containing $18.8 \mathrm{~kJ} / \mathrm{g}$ energy based on calculation (Garling and Wilson 1976; NRC 1993). In the diets, wheat flour and $\alpha$-potato starch were used as carbohydrate sources to adjust the energy content of the experimental diets. Carboxymethylcellulose (CMC) of high viscosity was used
Table 1 Composition of the experimental diets (\% of dry matter basis)

\begin{tabular}{lrrrrr}
\hline Ingredients & \multicolumn{6}{l}{ Protein level in the diets (\%) } \\
\cline { 2 - 6 } & \multicolumn{1}{c}{35} & \multicolumn{1}{l}{40} & \multicolumn{1}{c}{45} & \multicolumn{1}{c}{50} & \multicolumn{1}{c}{60} \\
\hline White fish meal $^{\mathrm{a}}$ & 25.00 & 20.00 & 15.00 & 10.00 & 5.00 \\
Casein $^{\mathrm{b}}$ & 15.80 & 24.50 & 33.30 & 42.00 & 55.80 \\
a-potato starch $^{\mathrm{a}}$ & 28.94 & 25.45 & 21.80 & 18.25 & 9.70 \\
Wheat flour $^{\mathrm{C}}$ & 7.00 & 7.00 & 7.00 & 7.00 & 7.00 \\
Squid liver oil $^{\mathrm{d}}$ & 16.21 & 16.00 & 15.85 & 15.70 & 15.45 \\
Vitamin premix. $^{\mathrm{e}}$ & 3.00 & 3.00 & 3.00 & 3.00 & 3.00 \\
Mineral premix. $^{f}$ & 3.00 & 3.00 & 3.00 & 3.00 & 3.00 \\
Vitamin C $^{\mathrm{g}}$ & 0.05 & 0.05 & 0.05 & 0.05 & 0.05 \\
Carboxymethylcellulose $^{\mathrm{b}}$ & 1.00 & 1.00 & 1.00 & 1.00 & 1.00 \\
\hline
\end{tabular}

aSuhyup feed Co. Ltd., Uiryeong, Korea

bUnited States Biochemical, Cleveland, OH, USA

'Young Nam Flour Mills Co., Busan, Korea

${ }^{\mathrm{d}}$ Ewha Oil Co., Ltd., Busan, Korea

${ }^{e}$ Contains (as mg/kg in diets) ascorbic acid, 300; dl-calcium pantothenate, 150; choline bitartrate, 3000; inositol, 150; menadione, 6; niacin, 150; pyridoxine. $\mathrm{HCl}$ 15; riboflavin, 30; thiamine mononitrate, 15; dl-a-tocopherol acetate, 201; retinyl acetate, 6 ; biotin, 1.5; folic acid, 5.4; $\mathrm{B}_{12}, 0.06$

${ }^{\mathrm{f} C o n t a i n s}$ (as $\mathrm{mg} / \mathrm{kg}$ in diet) $\mathrm{Al}, 1.2 ; \mathrm{Ca}, 5000 ; \mathrm{Cl}, 100 ; \mathrm{Cu}, 5.1 ; \mathrm{Co}, 9.9 ; \mathrm{Na}, 1280$;

$\mathrm{Mg}, 520 ; \mathrm{P}, 5000 ; \mathrm{K}$, 4300; Zn, 27; Fe, 40.2; I, 4.6; Se, 0.2; Mn, 9.1

${ }^{9}$ Vitamin C: L-ascorbyl-2-monophosphate, $35 \%$ ascorbic acid activity

(Hoffmann La Roche, Switzerland)

as binder. The experimental diets were also fortified with vitamin and mineral premixes (Table 1). The actual nutrients and amino acid contents in experimental diets are shown in Table 2. All ingredients were mixed and pelleted by a pelleting machine without heating using a 2-mm-diameter module (Baokyong Commercial Co., Busan, Korea). After air drying for $48 \mathrm{~h}$, all the pellets were broken up, sieved into the proper pellet size, sealed, and kept at $-20{ }^{\circ} \mathrm{C}$ until used.

\section{Fish and feeding trial}

Juvenile barred knifejaw, O. fasciatus, were transported from Geoje Marine Hatchery (Geoje, Korea) of the National Fisheries Research and Development Institute, Republic of Korea, to Youngchang Fisheries Farm (Tongyeong, Republic of Korea). Before commencement of the experiment, barred knifejaw were acclimated in a circular concrete tank containing $5000 \mathrm{~L}$ water where they were fed commercial diet for 2 weeks at the fish farm. A feeding trial was conducted in a rectangular concrete tank (5 $\mathrm{m} \times 5 \mathrm{~m} \times 3 \mathrm{~m}, W \times L \times H)$ having a flow-through system, containing 15 floating net cages (each size: $60 \mathrm{~cm} \times$ $40 \mathrm{~cm} \times 90 \mathrm{~cm}, W \times L \times H)$ in triplicates of each experimental diet. Flow rate was adjusted to ensure adequate circulation of seawater. Supplemental aeration was provided to maintain dissolved oxygen levels near saturation. Water temperature was maintained $19^{\circ} \mathrm{C}$ at the beginning of the feeding trial and was $22^{\circ} \mathrm{C}$ at the end of the feeding trial according to the normal changes of natural water temperature. Twenty fish weighing $7.1 \pm 0.06 \mathrm{~g}$ (mean \pm 
Table 2 Proximate composition and amino acid contents of experimental diets (\% of dry matter basis)

\begin{tabular}{llllll}
\hline Parameters & \multicolumn{5}{l}{ Protein levels (\%) } \\
\cline { 2 - 6 } & 35 & 40 & 45 & 50 & 60 \\
\hline Moisture & 25.9 & 26.9 & 25.8 & 27.1 & 26.9 \\
Crude protein & 35.0 & 40.6 & 44.8 & 50.2 & 60.1 \\
Crude lipid & 18.8 & 18.1 & 17.6 & 17.0 & 16.3 \\
Crude ash & 8.8 & 9.3 & 9.8 & 10.2 & 8.0 \\
Estimated energy $\left(\mathrm{KJ} \mathrm{g}^{-1}\right)$ & 18.7 & 18.8 & 18.8 & 18.7 & 18.8 \\
P/E ratio & 18.7 & 21.6 & 23.8 & 26.8 & 31.9 \\
Amino acids & & & & & \\
$\quad$ Arg & 2.11 & 2.36 & 2.43 & 3.52 & 3.61 \\
$\quad$ His & 1.08 & 1.28 & 1.38 & 1.52 & 1.58 \\
$\quad$ Lys & 3.51 & 4.11 & 4.36 & 5.16 & 5.63 \\
Leu & 3.12 & 3.72 & 3.88 & 4.23 & 4.38 \\
Ile & 2.52 & 2.81 & 3.25 & 3.56 & 3.67 \\
Met & 1.21 & 1.38 & 1.51 & 1.58 & 1.76 \\
Cys & 0.33 & 0.42 & 0.48 & 0.58 & 0.72 \\
Phe & 1.72 & 2.02 & 2.21 & 2.62 & 2.78 \\
Tyr & 1.63 & 1.79 & 2.23 & 2.38 & 2.54 \\
Thr & 1.32 & 1.43 & 2.36 & 2.53 & 2.69 \\
Trp & 0.36 & 0.56 & 0.68 & 0.72 & 0.83 \\
Val & 2.63 & 2.76 & 3.53 & 3.66 & 3.88 \\
\hline Valnes & & & &
\end{tabular}

Values are means of duplicate samples of each diet
SD) were randomly distributed to each net cage. Fish were fed one of the experimental diets twice (0900 and $1800 \mathrm{~h}$ ) a day to apparent satiation at the rate of $4 \%$ of wet body weight in the first 4 weeks and $3 \%$ in the second 4 weeks. Total body weight of the fish in each cage was determined every 2 weeks, and the feed amounts were adjusted accordingly. The experiment was conducted under the guidelines of the Animal Ethics Committee Regulations, No. 554, issued by Pukyong National University, Busan, Republic of Korea.

\section{Sample analyses and measurements}

At the end of the feeding trial, weight gain (WG), feed efficiency (FE), specific growth rate (SGR), protein efficiency ratio (PER), hepatosomatic index (HSI), condition factor (CF), protein retention efficiency (PRE), energy retention efficiency (ERE), hematocrit (percentage of packed cell volume-PCV\%), hemoglobin ( $\mathrm{Hb}$ ), and survival rate of juvenile barred knifejaw were determined (Table 3). After the final weighing, five fish were randomly collected from each aquarium and blood samples were obtained using heparinized syringes from the caudal vein and pooled for blood hemoglobin and hematocrit determination (Brown 1980). For the determination of HSI, liver weight was taken by dissecting the fish. Crude protein, moisture, and ash of whole-body samples were analyzed by AOAC methods (1995). In brief, samples of diets and fish were dried to a constant weight at $135{ }^{\circ} \mathrm{C}$ for $2 \mathrm{~h}$ to determine moisture content.

Table 3 Growth performance and hematological characteristics of juvenile barred knifejaw fed diets with five different protein levels for 8 weeks

\begin{tabular}{|c|c|c|c|c|c|}
\hline \multirow[t]{2}{*}{ Parameters } & \multicolumn{5}{|c|}{ Protein level in the diets (\%) } \\
\hline & 35 & 40 & 45 & 50 & 60 \\
\hline$\overline{W G(\%)^{1}}$ & $161 \pm 5.7^{c}$ & $171 \pm 2.5^{b}$ & $181 \pm 3.1^{a}$ & $182 \pm 5.7^{a}$ & $181 \pm 6.1^{a}$ \\
\hline $\mathrm{FE}(\%)^{2}$ & $70.9 \pm 2.3^{b}$ & $75.9 \pm 3.4^{\mathrm{ab}}$ & $82.0 \pm 2.4^{\mathrm{a}}$ & $81.7 \pm 2.7^{\mathrm{a}}$ & $79.8 \pm 2.9^{\mathrm{a}}$ \\
\hline SGR $(\% / \text { day })^{3}$ & $1.85 \pm 0.05^{c}$ & $1.94 \pm 0.02^{b}$ & $2.00 \pm 0.04^{\mathrm{a}}$ & $2.01 \pm 0.04^{\mathrm{a}}$ & $2.00 \pm 0.05^{a}$ \\
\hline $\mathrm{PER}^{4}$ & $2.03 \pm 0.07^{\mathrm{a}}$ & $1.86 \pm 0.06^{\mathrm{ab}}$ & $1.48 \pm 0.07^{b}$ & $1.44 \pm 0.07^{b}$ & $1.33 \pm 0.05^{c}$ \\
\hline $\mathrm{HSI}^{5}$ & $3.23 \pm 0.05^{\mathrm{ab}}$ & $3.32 \pm 0.05^{\mathrm{a}}$ & $3.19 \pm 0.06^{\mathrm{ab}}$ & $3.08 \pm 0.04^{b}$ & $3.03 \pm 0.03^{c}$ \\
\hline $\mathrm{CF}^{6}$ & $2.55 \pm 0.06^{b}$ & $2.71 \pm 0.07^{\mathrm{ab}}$ & $2.83 \pm 0.09^{a}$ & $2.81 \pm 0.07^{\mathrm{a}}$ & $2.78 \pm 0.05^{a}$ \\
\hline $\operatorname{PRE}(\%)^{7}$ & $35.1 \pm 2.9^{\mathrm{a}}$ & $28.2 \pm 3.5^{\mathrm{ab}}$ & $26.3 \pm 1.8^{\mathrm{b}}$ & $26.1 \pm 2.0^{b}$ & $23.5 \pm 2.3^{c}$ \\
\hline $\operatorname{ERE}(\%)^{8}$ & $37.9 \pm 3.1^{\mathrm{b}}$ & $43.2 \pm 3.5^{\mathrm{a}}$ & $44.9 \pm 2.9^{\mathrm{a}}$ & $41.6 \pm 28^{\mathrm{ab}}$ & $42.9 \pm 2.7^{\mathrm{a}}$ \\
\hline Hematocrit (\%) & $32.4 \pm 1.9$ & $29.3 \pm 2.9$ & $28.9 \pm 3.2$ & $30.4 \pm 2.1$ & $31.1 \pm 2.8$ \\
\hline Hemoglobin (g/dl) & $5.9 \pm 0.4^{b}$ & $6.8 \pm 0.6^{\mathrm{a}}$ & $7.3 \pm 1.0^{\mathrm{a}}$ & $7.1 \pm 0.8^{\mathrm{a}}$ & $6.8 \pm 0.6^{\mathrm{a}}$ \\
\hline Survival rate (\%) & $98.3 \pm 2.9^{\mathrm{a}}$ & $98.3 \pm 2.9^{a}$ & $100^{\mathrm{a}}$ & $100^{\mathrm{a}}$ & $95.0 \pm 5.0^{\mathrm{b}}$ \\
\hline
\end{tabular}

Values are means from triplicate groups of fish where the means in each row with a different superscript are significantly different $(P<0.05)$

${ }^{1}$ Percent weight gain: (final wt. - initial wt.) $\times 100 /$ initial wt

${ }^{2}$ Feed efficiency: (wet weight gain/dry feed intake) $\times 100$

${ }^{3}$ Specific growth rate: $100 \times($ In final wt. - In initial wt.)/days

${ }^{4}$ Protein efficiency ratio: (wet weight gain/protein intake) $\times 100$

${ }^{5}$ Hepatosomatic index: (liver weight/body weight) $\times 100$

${ }^{6}$ Condition factor: [fish wt. $(\mathrm{g}) /$ fish length $\left.(\mathrm{cm})^{3}\right] \times 100$

${ }^{7}$ Protein retention efficiency: [(final total body protein - initial total body protein)/total dietary protein fed] $\times 100$

${ }^{8}$ Energy retention efficiency: [(final total body energy - initial total body energy)/total dietary energy fed] $\times 100$ 
Ash was determined by incineration using a muffle furnace at $550{ }^{\circ} \mathrm{C}$ for $3 \mathrm{~h}$. Crude lipid was determined by Soxhlet extraction unit using the Soxtec System 1046 (Foss, Hoganas, Sweden), and crude protein content was analyzed by Kjeldahl method $(N \times 6.25)$ after acid digestion. Amino acids were measured with an automatic amino acid analyzer (S433; Sykam, Gilching, Germany).

\section{Statistical analysis}

All the data were subjected to one-way ANOVA using SAS version 9.1 software (SAS Institute, Cary, NC, USA) to test the effects of dietary protein levels (Zar 1984). When a significant treatment effect was observed, a least significant difference (LSD) test was used to compare the differences between treatment means $(P<0.05)$. Broken-line analysis (Robbins et al. 1979) was used to estimate the optimum level of protein requirement for juvenile barred knifejaw.

\section{Results}

The growth performance of barred knifejaw fed experimental diets at different protein levels is shown in Table 3. After 8 weeks of feeding trial, WG of the fish fed the 45,50 , and $60 \%$ crude protein $(\mathrm{CP})$ were significantly higher than those of the fish fed the 35 and $40 \%$ $\mathrm{CP}$ diets $(P<0.05)$. However, there were no significant differences in WG among the fish fed the 45, 50, or $60 \%$ CP diets. FE was significantly lower in the fish fed the $35 \% \mathrm{CP}$ than in the fish fed the 45,50 , and $60 \% \mathrm{CP}$ diets $(P<0.05)$. In contrast to WG and FE, PER and PRE decreased with increasing dietary protein levels. The highest and the lowest ERE values were observed at the 60 and $35 \% \mathrm{CP}$ levels, respectively. HSI was highest at the $35 \%$ CP level, whereas the lowest HSI was observed at the $60 \% \mathrm{CP}$ level. CF followed the same trend like FE of fish at different protein levels. A significantly higher mortality was observed in the fish fed the $60 \% \mathrm{CP}$ diet compared to the fish fed the $35,40,45$, and $50 \% \mathrm{CP}$ diets. In considering hematological characteristics of fish, the juvenile barred knifejaw fed the $35 \%$ CP diet showed a significantly lower hemoglobin level than the fish fed the $40,45,50$, and $60 \% \mathrm{CP}$ diets $(P<0.05)$. There were no significant differences in hematocrit levels among the fish fed the experimental diets $(P>0.05)$.

The whole-body proximate composition of juvenile barred knifejaw is shown in Table 4. The table shows that $\mathrm{CP}$ and crude lipid (CL) content in the whole body increased with the increase in dietary protein levels. Significantly higher whole-body $\mathrm{CP}$ content was found in the fish fed the 45,50 , and $60 \%$ CP diets than in the fish fed the 35 and $40 \%$ CP diets. Whole-body CL content was found highest in the fish fed the $50 \% \mathrm{CP}$ diet and lowest in the fish fed the $40 \%$ CP diet. No significant
Table 4 Proximate composition (\%) of the whole body of juvenile barred knifejaw Oplegnathus fasciatus fed the experimental diets for 8 weeks

\begin{tabular}{lcccc}
\hline Protein levels (\%) & Moisture & Crude protein & Crude lipid & Crude ash \\
\hline 35 & $66.5 \pm 1.1$ & $15.9 \pm 0.1^{\mathrm{b}}$ & $9.5 \pm 0.3^{\mathrm{ab}}$ & $4.3 \pm 0.3$ \\
40 & $65.3 \pm 1.0$ & $15.8 \pm 0.3^{\mathrm{b}}$ & $9.2 \pm 0.2^{\mathrm{b}}$ & $4.2 \pm 0.1$ \\
45 & $66.1 \pm 0.6$ & $16.5 \pm 0.3^{\mathrm{a}}$ & $9.8 \pm 0.1^{\mathrm{a}}$ & $4.1 \pm 0.2$ \\
50 & $65.0 \pm 0.8$ & $16.5 \pm 0.3^{\mathrm{a}}$ & $10.1 \pm 0.2^{\mathrm{a}}$ & $4.0 \pm 0.3$ \\
60 & $65.5 \pm 0.9$ & $16.8 \pm 0.2^{\mathrm{a}}$ & $10.0 \pm 0.2^{\mathrm{a}}$ & $4.3 \pm 0.2$ \\
\hline
\end{tabular}

Values are means from triplicate groups of fish where the means in each column with a different superscript are significantly different $(P<0.05)$

differences were found in the fish fed the experimental diets in terms of whole-body ash and moisture contents.

Broken-line analysis of WG of juvenile barred knifejaw indicated that the optimum dietary protein level was $45.2 \%$ (Fig. 1).

\section{Discussion}

After 8 weeks of the feeding trial, ANOVA showed that WG of the fish fed the $45 \%$ CP diet was significantly higher than those of the fish fed the 35 and $40 \% \mathrm{CP}$ diets but not significantly different from those of the fish fed the 50 and $60 \%$ CP diets (Table 3). However, based on broken-line analysis of WG of barred knifejaw, the optimum dietary protein was $45.2 \%$. Similarly, Kim et al. (2004) reported that the optimum dietary protein level for Korean rockfish was $45.1 \%$ CP based on broken-line analysis. In contrast to the present study, Kang et al. (1998) postulated that the optimum dietary protein level should be $46 \%$ for the same species when reared in tank condition. Lovell (1972) reported that the protein requirement of fish varies on the culture environment. Hastings and Dupree (1969) found that channel catfish fed a practical-type diet containing $40 \%$ protein showed linear growth in terms of WG in an aquarium system, whereas the same species of fish fed the same diet with

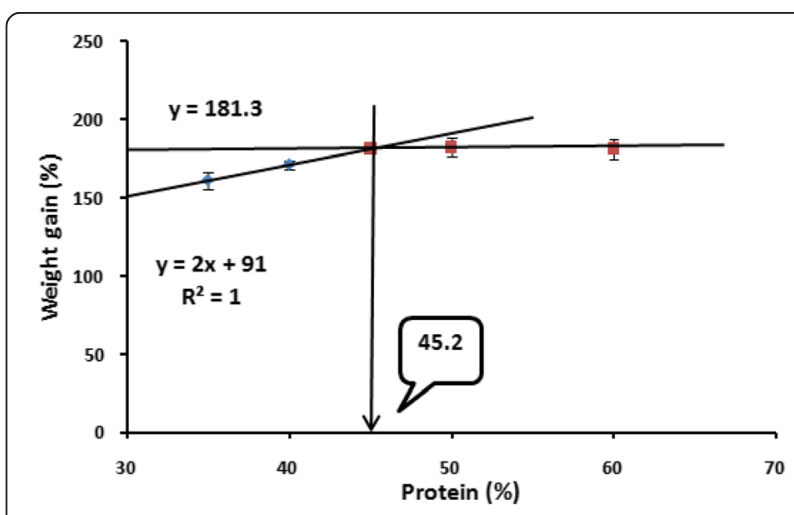

Fig. 1 Broken-line model of percent weight gain in barred knifejaw fed five different levels of dietary protein for 8 weeks 
$38 \%$ protein showed linear WG in a pond. Moreover, Lovell (1972) proposed that in the cage culture system the required protein level could be $40 \%$ for the same species of fish. Luo et al. (2004) reported that protein requirements for grouper fish species vary over a wide range between 40 and $60 \%$ depending on the species and culture condition.

In line with our result, the protein requirement of black sea bass, C. striata, was found to be $45.3 \%$ (Alam et al. 2008); $45 \%$ for European sea bass, Dicentrarchus labrax (Peres and Oliva-Teles 1999); and $45 \%$ for Florida pompano, Trachinotus carolinus (Lazo et al. 1998). However, in relation to the present study, the protein requirement levels were higher in olive flounder, $P$. olivaceus (46.4 \%; Kim et al. 2002); grouper, Epinephelus malabaricus (47.8\%; Chen and Tsai 1994); and silver pomfret, P. argenteus (49\%; Hossain et al. 2010), and lower in hybrid striped bass, Morone chrysops $\times$ Morone saxatilis (40 \%; Gatlin et al. 1994) and white bass, $M$. chrysops (41 \%; Rudacille and Kohler 1998). Generally, when dietary protein levels increase, the growth of fish also increases (NRC 1993). In this experiment, WG, FE, SGR, and CF of fish improved with increasing dietary protein levels up to $45 \% \mathrm{CP}$, and then, no further improvements were observed in these parameters at higher protein levels (Table 2). The trends were in agreement with Kim et al. (2004).

In the present study, there were clear reducing trends of PER and PRE with an increasing protein level in the treatment groups (Table 3 ). The result shows that possibly the dietary protein was efficiently utilized by fish for protein synthesis which is in agreement with Berger and Halver (1987). Similar results have been reported in other fish species (Bai et al. 1999; Kim et al. 2004; Kim et al. 2005; Hossain et al. 2010; Zhang et al. 2010). However, Kikuchi et al. (1992) and Lee et al. (2000) reported that PER values of olive flounder increased with increasing dietary protein levels. In another study, Dabrowski (1979) reported that the relationship between dietary protein and PER differs from species to species. In the present study, ERE increased with the increase of dietary protein levels which means dietary protein could be spared by nonprotein energy sources. Dietary protein sparing helps to reduce feed cost and nitrogen waste outputs (Wang et al. 2006). Ng et al. (2008) reported that lipid plays an important role for protein sparing when the dietary protein level is low in relation to the requirement.

Hematological parameters like hemoglobin $(\mathrm{Hb})$ and hematocrit $(\mathrm{PCV})$ concentration levels were more or less similar in all the treatment groups (Table 3). A significantly lower amount of $\mathrm{Hb}$ was found in the blood of the fish fed the $35 \%$ CP diet compared with the other experimental fish fed the higher levels of $\mathrm{CP}$-contained diets. However, PCV concentration level was more or less similar in all the dietary treatment groups which may have resulted in no abnormalities in health status of the experimental fish. Kim et al. (2004) also found dietary protein levels have no significant effect on the hematological and serological characteristics of juvenile Korean rockfish. Hepatosomatic index (HSI) indicates the body condition of fish. In this study, HSI of barred knifejaw decreases with the protein level increases in all the dietary treatments which may indicate higher utilization of protein levels from the diets which is in agreement with Kim and Lall (2001). Survival rates in the fish fed the $60 \%$ CP diet showed significantly higher mortality than those of the fish fed the $35,40,45$, and $50 \% \mathrm{CP}$ diets possibly due to the production of a high level of nitrogenous wastes by the fish through higher fecal output which pollutes the culture environment (Catacutan and Coloso 1995; Tibbetts et al. 2000; Alam et al. 2008).

Proximate compositions in terms of moisture and ash contents of the fish fed the experimental diets were not significantly affected by dietary protein levels (Table 4) which are in accordance with Okorie et al. (2007) for juvenile Japanese eel and Kim et al. (2004) for Korean rockfish. In this experiment, the whole-body CP content increased with the increasing dietary protein levels which agree with the result found by Kim et al. (2002). Similarly, the body lipid content generally increased as the dietary protein level increased which is in agreement with Shiau and Lan (1996) for grouper and Bai et al. (1999) for yellow puffer. On the contrary, Kim et al. (2002) reported that as the CP content of the whole body increases, the whole-body CL content decreases.

\section{Conclusions}

In conclusion, based on broken-line analysis of WG, it can be corroborated that the optimum dietary protein level could be $45.2 \%$ in juvenile barred knifejaw to achieve maximum growth when dietary energy content was fixed at $18.8 \mathrm{~kJ} / \mathrm{g}$ diet. From this present finding, we assume that a cost-effective practical feed could be developed for the sustainable production of barred knifejaw in floating net cages.

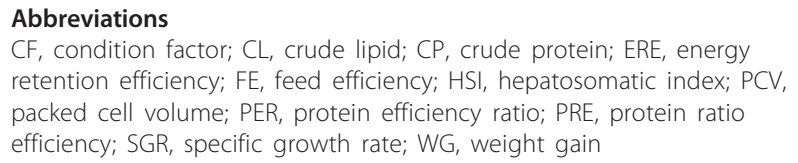

\section{Acknowledgements}

This research was supported by a grant (R2016016) from the National Institute of Fisheries Science (NIFS) and Feeds and Foods Nutrition Research Center (FFNRC) at Pukyong National University, Republic of Korea.

\section{Availability of data and materials}

The datasets supporting the conclusions of this article are included within the article. There is no additional data and materials to disclose. 


\section{Authors' contributions}

KWK conducted the research, analyzed the samples, and prepared the draft manuscript; MM helped to write the draft manuscript; KDK and HSH helped in the research design and reviewed the manuscript; $\mathrm{HY}$ and $\mathrm{SL}$ helped for the statistical analysis; and SCB designed and monitored the experiment and finalized the draft manuscript. The manuscript has been read and approved by the authors, and none of its parts has been submitted and published elsewhere. The authors also declare that nobody who qualifies for authorship has been excluded from the list of authors.

\section{Competing interests}

The authors declare that they have no competing interests.

\section{Author details}

${ }^{1}$ Aquafeed Research Center, National Institute of Fisheries Science (NIFS), Pohang 791-923, Republic of Korea. ${ }^{2}$ Department of Marine Bio-materials and Aquaculture/Feeds and Foods Nutrition Research Center, Pukyong National University, Busan 608-737, Republic of Korea.

Received: 24 February 2016 Accepted: 25 June 2016

Published online: 07 July 2016

\section{References}

Alam MS, Watanabe WO, Carroll PM. Dietary protein requirements of juvenile black sea bass, Centropristis striata. J World Aqua Soc. 2008;39:656-63.

Association of Official Analytical Chemists (AOAC). Official methods of analysis. Arlington: Association of Official Analytical Chemists, Inc; 1995.

Bai SC, Wang XJ, Cho ES. Optimum dietary protein level for maximum growth of juvenile yellow puffer. Fish Sci. 1999;65:380-3.

Berger A, Halver JE. Effect of dietary protein, lipid and carbohydrate content on the growth feed efficiency and carcass composition of striped bass, Morone saxatills (Walbaum), fingerlings. Aqua Res. 1987;18:345-56.

Brown BA. Hematology: principles and procedures. Philadelphia: Lea and Febiger; 1980.

Catacutan MR, Coloso RM. Effect of dietary protein to energy ratios on growth, survival, and body composition of juvenile Asian seabass, Lates calcarifer. Aquaculture. 1995;131:125-33.

Chen HY, Tsai JC. Optimum dietary protein level for the growth of juvenile grouper, Epinephelus malabaricus, fed semi-purified diets. Aquaculture. 1994;119:265-71.

Dabrowski K. Feeding requirement of fish with particular attention to common carp. A review. Polish Arch Hydrobiol. 1979;26:135-58.

Das KM, Mohanty S, Sarkar S. Optimum dietary protein to energy ratio for Labeo rohita fingerlings. In: De Silva S, editor. Fish nutrition research in Asia, Proceedings, Fourth Asian Fish Nutrition Workshop, Special Publication 5. Philippines: Asian Fisheries Society; 1991. p. 69-74.

El-Sayed AM, Teshima S. Protein and energy requirements of Nile tilapia, Oreochromis niloticus, fry. Aquaculture. 1992;103:55-63.

Garling DI, Wilson RP. Optimum dietary protein to energy ratio for channel catfish fingerlings, Ictalurus punctatus. J Nutr. 1976;106:1368-75.

Gatlin III DM, Brown ML, Keembiyehetty CN, Jaramillo Jr F, Nematipour GR. Nutritional requirements of hybrid striped bass (Morone chrysops $\times M$. saxatilis). J World Aqua Soc. 1994;33:97-109.

Halver JE, Hardy RW. Fish nutrition. 3rd ed. San Diego: Academic; 2002.

Hastings WH, Dupree HK. Practical diets for channel catfish. Progress in sport fisheries research 1968, vol. 77. USA: U.S. Dept. of Interior, Bureau of Sport Fisheries and Wildlife Res. Public; 1969. p. 224-6.

Hepher B. Nutrition of pond fishes. Sydney: Cambridge University Press; 1988.

Hossain MA, Almatar SM, James CM. Optimum dietary protein level for juvenile silver pomfret, Pampus argenteus (Euphrasen). J World Aqua Soc. 2010;41: $710-20$.

Kang YJ, Lee SM, Hwang HK, Bai SC. Optimum dietary protein and lipid levels on growth in parrot fish (Oplegnathus fasciatus). J Aquaculture (Korean). 1998;11:1-10.

Kikuchi K, Sugita H, Watanabe T. Effect of dietary protein level on growth and body composition of Japanese flounder, Paralichthys olivaceus. Suisanzoshoku. 1992;40:335-40.

Kim JD, Lall SP. Effects of dietary protein level on growth and utilization of protein and energy by juvenile haddock (Melanogrammus aeglefinus). Aquaculture. 2001;195:311-9.
Kim KW, Wang XJ, Bai SC. Optimum dietary protein level for maximum growth of juvenile olive flounder, Paralichthys olivaceus (Temminck et Schlegel). Aqua Res. 2002;33:673-9.

Kim KW, Wang XJ, Han K, Kang JC, Bai SC. Optimum dietary protein level and protein-to-energy ratio for growth of juvenile Korean rockfish Sebastes schlegeli. J World Aqua Soc. 2004;35:305-14.

Kim KW, Kang YJ, Choi SM, Wang XJ, Choi YH, Bai SC, Lee JY, Jo JY. Optimum dietary protein levels and protein to energy ratios in olive flounder Paralichthys olivaceus. J World Aqua Soc. 2005;36:165-78.

Lazo JP, Davies DA, Arnold CR. The effects of dietary protein level on growth, feed efficiency and survival of juvenile Florida pompano (Trachinotus carolinus). Aquaculture. 1998;169:225-32.

Lee SM, Cho SH, Kim KD. Effects of dietary protein and energy levels on growth and body composition of juvenile flounder, Paralichthys olivaceus. J World Aqua Soc. 2000;36:165-78.

Lovell RT. Protein requirements of cage-cultured channel catfish, Proceedings of the 26th annual conference of the Southeastern Association of Game and Fish Commissioners. 1972. p. 357-61.

Lovell RT. Nutrition and feeding of fish. New York: Van Nostrand-Reinhold; 1989.

Luo Z, Liu YJ, Mai KS, Tian LX, Liu DH, Tan XY. Optimal dietary protein requirement of grouper Epinephelus coioides juveniles fed isoenergetic diets in floating net cages. Aqua Nutr. 2004;10:247-52.

Meng QW, Su JX, Miao XZ. Fish taxonomy. Beijing: China Agriculture Press; 1995. p. 734-56.

National Research Council (NRC). Nutrient requirements of fish. Washington, D.C.: National Academy Press; 1993

National Statistical Office. Survey on the status of fish culture. Daejeon: National Statistical Office; 2014

Ng WK, Abdullah N, De Silva SS. The dietary protein requirement of the Malaysian mahseer, Tor tambroides (Bleeker), and the lack of protein-sparing action by dietary lipid. Aquaculture. 2008;284:201-6.

Okorie EO, Kim YC, Lee S, Bae JY, Yoo JH, Han K, Park GJ, Choi SM, Bai SC. Reevaluation of the dietary protein requirements and optimum dietary protein to energy ratios in Japanese eel, Anguilla japonica. J World Aqua Soc. 2007;38:418-26.

Peres $\mathrm{H}$, Oliva-Teles A. Effect of dietary lipid level on growth performance and feed utilization by European sea bass juveniles (Dicentrarchus labrax). Aquaculture. 1999;179:325-34.

Robbins KR, Norton HW, Baker DH. Estimation of nutrient requirements from growth data. J Nutr. 1979;109:1710-4.

Rudacille JB, Kohler CC. Dietary protein requirement of juvenile white bass, Morone chrysops (book of abstract). Aquaculture. 1998;98:457-8.

Shiau SY, Lan CW. Optimum dietary protein level and protein to energy ratio for growth of grouper (Epinephelus malabaricus). Aquaculture. 1996;145:259-66.

Tibbetts SM, Lall SP, Anderson DM. Dietary protein requirement of juvenile American eel (Anguilla rostrata) fed practical diets. Aquaculture. 2000;186: $145-55$.

Wang Y, Guo J, Li K, Bureau DP. Effects of dietary protein and energy levels on growth, feed utilization and body composition of cuneate drum, Nibea miichthioides. Aquaculture. 2006;252:421-8

Wilson RP. Amino acids and proteins. In: Halver JE, Hardy RW, editors. Fish nutrition. San Diego: Academic; 2002. Pages 144-179.

Zar JH. Biostatistical analysis. 2nd ed. Englewood Cliffs: Prentice-Hall International, Inc.; 1984.

Zhang J, Zhou F, Wang LL, Shao Q, Xu Z, Xu J. Dietary protein requirement of juvenile black sea bream, Sparus macrocephalus. J World Aqua Soc. 2010;41:151-64. 